\title{
Ethics and Social Welfare
}

\section{Epistemic injustice and epistemic redlining}

\section{Michael D. Doan}

To cite this article: Michael D. Doan (2017): Epistemic injustice and epistemic redlining, Ethics and Social Welfare, DOI: $10.1080 / 17496535.2017 .1293120$

To link to this article: http://dx.doi.org/10.1080/17496535.2017.1293120

曲 Published online: 22 Feb 2017.

Submit your article to this journal $\widetilde{ }$

View related articles ¿

View Crossmark data $\asymp$ 


\title{
Epistemic injustice and epistemic redlining
}

\author{
Michael D. Doan
}

History \& Philosophy Department, Eastern Michigan University, Ypsilanti, MI, USA

\begin{abstract}
The practice of Emergency Management in Michigan raises anew the question of whose knowledge matters to whom and for what reasons, against the background of what projects, challenges, and systemic imperatives. In this paper, I offer a historical overview of state intervention laws across the United States, focusing specifically on Michigan's Emergency Manager laws. I draw on recent analyses of these laws to develop an account of a phenomenon that I call epistemic redlining, which, I suggest, is a form of group-based credibility discounting not readily countenanced by existing, 'culprit-based' accounts of epistemic injustice. I argue that epistemic redlining plays a crucial role in ongoing projects of racialized subordination and dispossession in Michigan, and that such discounting tends to have structural causes that can be difficult to identify and uproot. Contrary to the general thrust of recent work on the topic, I argue that epistemic redlining ought to be understood as a form of epistemic injustice.
\end{abstract}

\section{KEYWORDS}

Epistemic injustice; oppression; violence; redlining; Michigan; Emergency Management; democracy; water; social justice

\section{Introduction}

Since 2013, I have been working with grassroots coalitions in Detroit to challenge legislation allowing the Governor of Michigan to appoint an Emergency Manager (EM) in cities facing fiscal distress. As Michigan residents have suspected for years, and as is becoming increasingly clear to the public at large, EMs have played pivotal roles in creating and sustaining water crises in Detroit and Flint (Cramer 2015; Hammer 2016; Howell, Doan, and Harbin 2016; WTPCRC 2016). It is through my involvement in collective efforts to resist Emergency Management that I have learned about state-level takeovers of cities, the curtailment of citizenship rights they entail, the publicly unaccountable decision-making they institutionalize, and the devastating outcomes of specific decisions. Decisions made by EMs have resulted in unprecedented rates of water shutoffs still ongoing in Detroit, and in mass lead poisoning and other forms of contamination linked to shifts in Flint's water supply. The public health and safety consequences have been severe. Working-class communities of color - particularly elders, children, people with disabilities, and those without documents - continue to bear the heaviest burdens.

In his recent testimony to the Michigan Civil Rights Commission (MCRC) Hearings on the Flint Water Crisis, law professor Peter Hammer emphasizes that, 
As it relates to Emergency Management, Flint is a story about whose knowledge matters; how the information and beliefs of particular groups can pre-determine policy; and how resistant established knowledge-\&-power matrices are to change, especially when challenged from below by groups historically marginalized in terms of race, ethnicity and national origin. $(2016,3)$

As Hammer goes on to add: 'Flint residents had knowledge of the water crisis almost immediately upon the switch to the Flint River' (35). Why, then, was their 'real and visceral' knowledge not taken up for months on end? Why have Flint residents not been taken seriously as knowers? Why has their knowledge not mattered to EMs, the Department of Treasury, the Department of Environmental Quality, or the Governor, whose inaction has prolonged and worsened the ongoing water crisis? And why have low-income, mostly African-American Detroiters been subjected to similar treatment while struggling to pay unaffordable water bills and facing shutoffs numbering in the tens of thousands? Why have the 'knowledge- $\&$-power matrices' of state officials been so resistant to change when 'challenged from below'?

As a social epistemologist involved in resisting Emergency Management, I have grown increasingly concerned with the patterns of unjust credibility discounting I have been witnessing throughout the State of Michigan. I have observed local elected officials - and, indeed, entire electorates in Flint, Detroit, and other predominantly black cities - continually subjected to cognitive undermining, particularly when addressing state officials and the media. In this paper, I argue that this pattern of credibility discounting is rooted in Michigan's legal structure. I claim that Emergency Management is an inherently violent practice insofar as it inflicts epistemic violence on entire populations, the consequences of which are predictably disastrous.

I begin by offering a historical overview of state intervention laws across the United States, focusing specifically on Michigan's EM laws. I draw on recent analyses of these laws to develop an account of a phenomenon that I call epistemic redlining, which, I suggest, is a form of unjust credibility discounting not readily countenanced by existing models of epistemic injustice. Finally, I consider how ongoing conversation concerning epistemic injustice might be broadened to accommodate the phenomenon of epistemic redlining. Contrary to the general thrust of recent work on the topic, I argue that epistemic redlining ought to be understood as a form of epistemic injustice in spite of the fact that it cannot be traced to prejudice and cannot be remedied through the cultivation of individual virtue. Because Michigan's legislature instituted an epistemic redlining policy when it passed the EM laws, the laws in question are inherently unjust.

\section{Historical overview of Emergency Management in Michigan}

\section{How did EM laws come into being?}

In the context of the United States, periods of economic crisis have repeatedly renewed interest in the questions of whether and under what circumstances state governments can intervene in the financial affairs of local governments. Federal courts started enabling state intervention during the Long Depression of 1873-79 when private creditors brought complaints about municipalities who had defaulted on debts used to finance the construction of railroad facilities (ACIR 1973, 9-11; Dimock 1935, 41-43, 1940, 193-194). The US 
Supreme Court ultimately upheld the constitutionality of municipal receivership in Meriwether v. Garrett (1880), making it possible for states and local elected officials to jointly appoint an individual or board to serve as financial receiver for a fiscally troubled municipality. The State of New Hampshire was the first to establish a 'Financial Control Board' when it took over the operations of the City of Manchester in 1921, setting the stage for the Great Depression of the 1930s, when several states started taking control of municipal financial affairs by temporarily placing cities in receivership (Berman 1995, 57; Dimock 1940, 194; Hren, Morelli, and Briggs 1997, 736).

A second generation of state intervention legislation was crafted during the recession of the early 1970s when larger cities such as New York and Philadelphia were confronting persistent financial problems. In the years preceding the 1970s, states tended to respond to municipal fiscal distress on an ad hoc basis, typically by offering bailouts to local governments in exchange for their consent to enter into regulative arrangements ranging from state oversight, on the one hand, to more or less complete control of municipal financial affairs, on the other, in which case a state-appointed board would 'dictate specific policy steps' (Berman 1995, 61). Yet over the course of the 1970s, 1980s, and 1990s, more than a dozen states started taking a 'multijurisdictional policy approach' to preventing and dealing with municipal fiscal distress (Cahill and James 1992, 90-91; Cahill et al. 1994, 254-255). Rather than focusing on the financial problems of local governments on a case-by-case basis, these states adopted statutes that apply to several categories of local government all at once (i.e. cities, townships, and school districts in general). States utilizing such general legislation to this day include Florida, Illinois, Indiana, Michigan, New Jersey, Ohio, North Carolina, Pennsylvania, and Rhode Island (Scorsone 2014, 12-13).

The State of Michigan has recently adopted a number of statutes for preventing and dealing with municipal fiscal distress. In 1986, when the City of Ecorse was facing a $\$ 6$ million budget shortfall, the Wayne County Circuit Court placed the city in receivership (HJCDF 2012, 1). In response to the Ecorse decision, the state legislature passed Public Act (PA) 101, which officially created the 'financial emergency' status and the 'Emergency Financial Manager' (EFM) position and outlined a process through which the Treasury could appoint an EFM to take control of a municipality's finances. PA 101 was signed into law by Governor James Blanchard of the Democratic Party in 1988. In 1990 it was amended and strengthened as PA 72, the 'Local Government Fiscal Responsibility Act', which broadened the powers of an EFM to cover all municipal financial affairs and included public school districts under the same legal framework. PA 72 was amended further under Governors John Engler and Jennifer Granholm, first by PA 265 of 1992, then by PA 408 of 2002, PA 282 of 2003, and PA 181 of 2009.

Governor Rick Snyder of the Republican Party took office in January 2011. In March 2011, the Republican-controlled state legislature passed PA 4, the 'Local Government and School District Fiscal Accountability Act', which shortened the title of 'Emergency Financial Manager' (EFM) to the simpler 'Emergency Manager' (EM) and significantly extended the scope of the EM's powers. As sociologists L. Owen Kirkpatrick and Nate Breznau (2016) point out, 'This seemingly innocuous change in nomenclature signals a pivotal shift', for 'the EM's authority was expanded well beyond the boundaries of the fiscal and financial, so as to include the political, the administrative, and the curricular'. PA 4 not only allows an EM to assume the responsibilities of all local elected officials, but as economist and local government finance specialist Eric Scorsone notes, it also 
gives an EM several 'quasi-judicial powers related to breaking contracts' $(2014,39)$. Specifically, the law grants an EM the power to modify or terminate existing collective bargaining agreements and to negotiate or ban entry into new ones; to contract out public services to private companies and sell off public assets, including buildings and infrastructure; and to dismiss public officials, set aside minimum staffing requirements, and consolidate or dissolve local departments.

These developments are significant. Public law scholar Michele Wilde Anderson argues that the passing of PA 4 marks the beginning of a third generation of state intervention legislation, for the law 'significantly and controversially amplified the power given to emergency managers' and 'permitted state intervention at earlier stages of financial deterioration and in a wider range of circumstances' $(2011,587)$. Without providing financial aid to struggling municipalities or so much as soliciting the consent of the governed, PA 4 enables the suspension of a city's charter and strips all elected officials of their powers, 'imposing the authority of the state through an appointee of the governor' who is accountable to no one else, and effectively stripping city residents of local citizenship rights (581). The unelected EM is charged with issuing a financial and operating plan that provides for payment in full of debt service on bonds, notes, securities, and so forth, and must present their plan to the public at an informational hearing. However, no local officials need be consulted during the process of devising said plan, and no public approval need be sought. For these reasons, Anderson describes PA 4 as bringing about a condition of 'democratic dissolution', by which she means 'changes that suspend local democracy, even though the city remains a legal entity' (581).

In the wake of numerous demonstrations and high-profile lawsuits, a citizen-led petition drive succeeded in getting PA 4 on a referendum ballot. The law was overturned in November 2012 when 53 percent of Michigan's citizens voted it down. Nevertheless, in December the state legislature passed PA 436, the 'Local Financial Stability and Choice Act', which functions similarly to its widely unpopular predecessor. Unlike PA 4, however, appropriations were written into the new law that effectively shield it from future public challenges. Simply put, the EM law currently on the books was designed to be referendum-proof.

Beginning in 2002, public school districts in Benton Harbor, Detroit, Highland Park, Inkster, Muskegon Heights, and Pontiac have been placed under the control of either an EFM, an EM, or both at different times. Since the onset of the global economic crisis in 2007 and 2008, nine municipalities in Michigan have been placed under the control of either an EFM, an EM, or both, including Benton Harbor, Detroit, Ecorse, Flint, Hamtramck, Highland Park, Lincoln Park, Pontiac, and River Rouge. Of the municipalities and school districts listed here, residents of the vast majority have been governed by more than one state-appointed administrator over periods of as many as 9 and 13 years (in the cases of Pontiac and Flint, respectively).

\section{Who is affected by EM laws?}

Emergency Management has disproportionately impacted Michigan's African-American residents. According to the most recent census data, the population of Benton Harbor is approximately 89.2 percent African-American, Detroit is 82.7 percent, Ecorse is 46.4 percent, Flint is 56.6 percent, and Pontiac is 52.1 percent (US Census Bureau 2010). As 
Kirkpatrick and Breznau (2016) have shown, between the years 2007 and 2013, '51.7\% of black Michigan residents had been subjected to emergency intervention, while only $2.7 \%$ of their white counterparts were similarly affected'. When Kevyn Orr was appointed as Detroit's EM in 2013, a total of more than 720,000 black Michiganders, or roughly 57 percent of the state's African-American population, were living without political representation in either their municipality or public school district.

Here, the question of epistemic injustice comes to the fore. As a number of legal scholars and economists have argued, state emergency intervention statutes both reflect and codify into law various theories, or causal stories, which are meant to explain why local governments wind up in a state of fiscal distress (Anderson 2011; Sapotichne et al. 2015; Scorsone 2014). Certain theories place greater emphasis on 'internal' causes of budget shortfalls, such as the misguided decision-making, incompetence, untrustworthiness, or corruption of local elected officials, and the dominance of special interest groups, such as public-sector unions, in local politics (Glaeser 2010, 2011a, 2011b, 2013; Malanga 2009, 2010, 2013; Steyn 2013). Other theories emphasize the relative importance of 'external' causes, such as shifts in federal and state revenue-sharing policies since the late 1970s; declining property values and property tax revenues in cities linked to federally subsidized suburbanization and white and middle-class flight begun decades prior; declining income tax revenues as a result of regional unemployment and underemployment linked to processes of industrial automation and the outsourcing and offshoring of labor and followed by capital abandonment, deindustrialization, and the emergence of service-oriented economies; 'innovative' and risky financial products with stiff penalties, marketed to cash-strapped city governments and residents by banks and financial institutions; and racial discrimination in education, employment, housing, health care, insurance, and so forth (Boggs 1963; Bluestone and Harrison 1982; Darden et al. 1987; Desan and Steinmetz 2015; Farley, Danziger, and Holzer 2000; Jackson 1985; Sapotichne et al. 2015; Scorsone and Bateson 2011; Sugrue 2005; Tabb 2015a, 2015b; Turbeville 2013). The stories a state legislature elects to tell itself and others about what factors do and do not contribute to producing fiscal distress clearly play a significant role in shaping the economic metrics and legal frameworks it ends up creating for enabling state interventions.

It is worth pausing to consider what types of stories state legislatures have been codifying into law across the United States. According to Scorsone, the 'operating theory, generalizing across the states, is that the internal side of the table is the source of the problems' $(2014,41)$. Yet very few laws even 'acknowledge the importance of institutional structure', because 'the idea behind these laws is that a local government has been unable to adapt to its circumstances and has fallen into a crisis that external actors must manage' (42). Reflecting on Michigan's EM laws in particular, Anderson emphasizes that by 'remediating the crisis only by replacing local government with state-appointed experts, the laws reflect theories of fiscal crisis that assume that local management - or more to the point, mismanagement - is solely to blame for fiscal meltdown', which, she argues, amounts to 'a gross oversimplification of the causes of fiscal decline' (2011, 610, 582; see also Desan and Steinmetz 2015, 18-20; Peck 2015, 159-162). Anderson's argument concerning the extent to which the state legislature both misdiagnoses and prescribes inadequate remedies for local financial problems is echoed in a more recent report by a team of scholars at Michigan State University, who point out that, 'if takeover is the 
solution, the problem is mismanagement' (Sapotichne et al. 2015, 19). 'Michigan codifies this causal story in a way that is less adulterated than in any other state we have surveyed', they continue, adding that 'the state has adopted and codified a vastly oversimplified story' (19, my emphasis; cf. Tabb 2015b, 64-67). Hammer summarizes the situation in Flint as follows: 'The primary, non-structural reason Flint was in financial distress was the direct result of state revenue sharing policy. This fact does not get the public attention it deserves. The State of Michigan created the very financial distress in Flint and other cities that it then used to supposedly justify the need for Emergency Managers' $(2016,8$, emphasis in original).

In summary, Michigan's EM laws, and the widely unpopular state takeovers they enable, are premised on the unargued assumption that the principal sources of municipal fiscal distress must lie within municipalities themselves. Whereas a great deal of ink has already been spilled on how these laws have been used to deprive residents of predominantly black cities of local democracy, there has been comparatively little reflection on the epistemic assumptions undergirding them, or on the effects of their public authorization and installation. Yet the idea that fiscal distress must stem from the incompetence and untrustworthiness of local elected officials - and of an entire electorate - is worth pausing to explore at some length. I am particularly interested in the extent to which this idea functions as an implicit justification for the practice of imposing EMs on majority black cities, while also helping to shield this practice and its consequences from contestation. I will now develop an account of a phenomenon that I call epistemic redlining, which, I suggest, is a structural form of unjust credibility discounting that is integral to Emergency Management.

\section{What is epistemic redlining?}

I borrow the name from a term coined by sociologist and community activist John McKnight in the late 1960s. 'Redlining' refers to the practice of denying financial services (e.g. mortgages, home repair loans) to residents of specific neighborhoods, generally because they are people of color and/or poor, and not because of their actual credit ratings or creditworthiness (Bartelt 2010; Ladd 1998). The practice is called 'redlining' because it literally involves drawing red lines on maps to delineate areas where banks will refuse to invest; meanwhile, green, yellow, and orange lines are drawn around neighborhoods whose residents are deemed to be of higher economic value. In the 1930s, the Home Owners' Loan Corporation (HOLC) instituted a redlining policy when it developed color-coded maps of cities across the United States, which were then widely adopted by private banks and insurers to guide the allocation of mortgages and home repair loans. These maps were also used by the Federal Housing Administration (FHA) to guide the construction of new housing to be purchased with federally insured mortgages (Jackson 1985, 195-218; Satter 2009, 41-47). Neighborhoods regarded as actual and potential minority enclaves were subjected to systematic disinvestment and underdevelopment when residents were deemed 'undesirable' owing to the racist and classist perceptions of realtors, public officials, and bankers (Jackson 1985, 198-201). At the same time, federal funds were allocated for the construction of new houses in the suburbs, which were promptly bought up by relatively affluent, predominantly white borrowers. Thus were suburban wealth and urban ghettoes created together. 
Again, in the case of redlining proper the denial of credit to residents of certain neighborhoods is not based on residents' actual credit ratings or creditworthiness, for lending practices are systematically distorted by false, identity-based prejudices. The phenomenon I am calling epistemic redlining involves an inversion in the order of reasoning characteristic of redlining proper (which, incidentally, takes many of the material consequences of redlining in housing as its point of departure). Epistemic redlining is the practice of denying conferrals of credibility to residents of specific municipalities, generally because those municipalities are deemed to be in a state of 'financial emergency'. In the Michigan context, I want to suggest that an epistemic redlining policy was instituted by the state legislature when it created the 'financial emergency' status and empowered the Governor to appoint EFMs (and later, EMs).

What Michigan's EM law says, in effect, is that being in a state of financial emergency is a mark of a local population's inability to govern themselves. Since competent epistemic agents are generally capable of self-governance, being in a state of financial emergency has also become an indirect indicator of being less than fully competent, and so not worthy of credibility, on matters of public policy. As Hammer puts it,

Emergency Managers do not have to listen to residents, because they are not popularly (re)elected. They report to Treasury and to the Governor. Treasury officials are unlikely to be predisposed to grant the complaints of people in cities like Flint much credibility. The whole premise of Emergency Management is that people like the residents of Flint cannot govern themselves. $(2016,36)$

Of course, advocates of the law insist that because the 'financial emergency' status is a politically neutral, essentially technical measure, the law is fair in the sense of being nondiscriminatory or non-prejudicial. The fact that its implementation just happens to have disproportionately impacted the state's African-American residents is simply due to the fact that African-Americans happen to live in fiscally distressed cities. But matters are not nearly so simple. For one thing, a study conducted by Kirkpatrick and Breznau (2016) has shown that, next to fiscal conditions, 'the percentage of black population in a local unit is also an independently significant predictor' of where an EM will be appointed in Michigan, which suggests that race has, in fact, played a role in the distribution of EMs. Moreover, from the point of view of the state, the act of appointing an EM to govern over the residents of a municipality entails a structural commitment to refusing to recognize them - and the officials they either have elected or might elect from amongst themselves - as competent epistemic agents, and hence to denying them conferrals of credibility.

Indeed, the act of signing PA 436 into law can be understood as an operation of discursive power whereby the state - and capitalist interests that deploy state violence to secure their positions - sanctioned and legitimized the misrecognition of certain geographically defined populations. Although the law's adoption does not literally involve drawing red lines on a state map, it is an act of spatial demarcation all the same insofar as it legitimizes the use of 'fiscal responsibility' as a proxy for the credibility of entire populations. Therein lies the cunning of epistemic redlining: without naming 'blacks', 'people of color', and 'the poor' as incapable of self-governance and hence incompetent, PA 436 enacts certain political distinctions on the basis of standardized measures of 'fiscal health', effectively excluding these groups from testifying and being heard on matters of public policy, not to 
mention from asking relevant questions, contesting claims and standards of evidence, and otherwise participating in informing the policies that most immediately shape their individual and collective lives.

Of course, epistemic redlining is only contingently related to the EM laws that have emerged in recent decades. There are likely to be other legal and extra-legal means of implementing practices of this sort, many of which have yet to be envisioned. The extent to which systems of settler colonialism and chattel slavery have relied upon epistemic redlining, or other, comparable practices, to buttress their explicitly and implicitly racist justifications for prevailing power relations has also yet to be explored. At any rate, part of what I have been suggesting is that the practice of epistemic redlining seems tailor-made for contemporary, officially colorblind contexts in which explicit references to race and class are generally frowned upon (especially when it comes to matters legal and legislative), which forces longstanding projects of racialized subordination and dispossession to adapt accordingly.

\section{Epistemic injustice and epistemic redlining}

Given that the practice of epistemic redlining has been gaining considerable traction in officially colorblind, 'post-racial' contexts, this raises the further question of whether epistemic redlining ought to be understood as a form of epistemic injustice. In this final section I explain why I have found recent philosophical work on epistemic injustice both insightful and constraining, and then consider how conversation concerning epistemic injustice might be broadened with a view to accommodating the phenomenon of epistemic redlining.

In her widely influential book, Epistemic Injustice, Miranda Fricker proposes to investigate 'injustice specifically in the sphere of epistemic activity' (2007, viii). She argues that epistemic injustice occurs whenever someone is 'wronged specifically in her capacity as a knower' (20, emphasis in original) and focuses on two forms that injustice of this sort may take. The first is testimonial, where a speaker's credibility is unduly discounted, and their testimony is not believed, owing to a negative, identity-based prejudice in their audience. Fricker offers the example of Tom Robinson from Harper Lee's novel, To Kill a Mockingbird. Robinson, a black man, has been charged with raping Mayella Ewell, a white woman, and must testify before an all-white jury. While it is obvious that Robinson is innocent of the crime and speaks truthfully in court, his testimony is not believed by the jury, whose credibility judgments are systematically distorted by anti-black prejudice. Robinson is not taken seriously in his capacity as a knower and is thereby damaged in his standing as a human being. Meanwhile, having written off their only reliable informant, the jury issues an under- and misinformed verdict and ends up imprisoning Robinson for a crime he did not commit. To prevent such injustices from occurring and to promote more successful testimonial exchanges, Fricker recommends cultivating the virtue of testimonial justice. Inculcating this virtue involves undergoing a profound shift in sensibility, through which the virtuous hearer effectively 'neutralizes the impact of prejudice in her credibility judgements' (emphasis in original), rendering her perceptions of her fellow speakers 'unprejudiced' (92, 93, emphasis in original).

The second form of epistemic injustice is hermeneutical, where a speaker is rendered incapable of making sense of her own social experiences, and of having them understood 
by others, owing to a persistent gap in epistemic resources rooted in group-based hermeneutical marginalization. Fricker offers the example of Carmita Wood, who struggles to articulate her experiences of dealing with her employer's unwanted sexual advances during a period when acts of this type had not yet been named 'sexual harassment'. When asked why she had sought transfers and eventually quit her job, Wood reflects on her employer's actions, struggles to find the words to describe them, and ultimately replies that her reasons for leaving were 'personal'. Wood is promptly refused unemployment insurance and suffers a number of associated hardships. Meanwhile, her employer insists that the way he would 'accidentally' brush his hand against her breasts when reaching across the table was nothing more than a bit of harmless 'flirting'. As Fricker explains, such readily available misinterpretations are made possible by the unequal hermeneutical participation of men and women in a patriarchal society. Feminist consciousness-raising collectives eventually created the more accurate term, 'sexual harassment', filling a significant hermeneutical gap. As Fricker puts it, 'Hermeneutical lacunas are like holes in the ozone - it's the people who live under them that get burned' (161). To reduce associated harms, Fricker recommends cultivating the virtue of hermeneutical justice, through which a hearer becomes 'reflexively aware of how the relation between his social identity and that of the speaker is impacting on the intelligibility to him of what she is saying and how she is saying it' (169). The virtuous hearer strives constantly to counteract the 'prejudicial impact' that a speaker's hermeneutical marginalization is likely to have had on the epistemic resources available to her, 'listening as much to what is not said as to what is said' $(168,172$, emphasis in original).

Contrary to some of the more provocative claims advanced by her commentators, I agree with Fricker that efforts to reveal additional forms of epistemic injustice are generally consistent with the broader project laid out in her 2007 book, given that she has 'always intended the idea of epistemic injustice as an umbrella category, open to further elaboration' (2010, 174; see also Dotson 2012, 41-42). Ever since the book's publication, the vast majority of writing on the subject has been devoted to identifying hitherto unrecognized forms of epistemic injustice (e.g. trust injustice and willful hermeneutical ignorance), most of which fit readily into the 'culprit-based' mold that Fricker is most widely known for developing (Kwong 2015, 228), and that has been the near exclusive focus of philosophers building upon her work (e.g. Hookway 2010; Kwong 2015; Marsh 2011; Origgi 2012; Pohlhaus 2012; Riggs 2012).

Part of what I have found constraining about recent conversation concerning epistemic injustice is precisely this focus on individual perpetrators, which, I fear, is a non-accidental by-product of the way the concept has taken shape. Since the publication of Epistemic Injustice, most philosophers working on the topic have accepted the following two tenets: first, credibility discounting must ultimately be traced to prejudice in order to be unjust; and second, there must be an individual remedy, in the form of a specific corrective virtue, for each and every variety of unjust discrediting. Allow me to unpack each tenet in turn.

Recall that, on Fricker's view, the denial or withholding of credibility is not necessarily unjust, and only becomes so when a speaker's credibility is unduly discounted because of an identity-based prejudice in their audience. The basic idea here is that the 'ethical poison of testimonial injustice must derive from some ethical poison in the judgement of the hearer', and that identity prejudice, with its 'ethically bad affective investment' and 
stubborn resistance to counter-evidence, is an appropriately poisonous source (Fricker $2007,22,36)$. Prejudice is more than a cause of epistemic injustice, for Fricker - it is a substantive criterion, or that which qualifies an instance of credibility discounting as an injustice (May 2012, 8). If this first tenet is accepted, then the second is likely to seem plausible as well; after all, if prejudice is an individual problem, it can probably be addressed by way of an individual remedy.

Now, recall that epistemic redlining is the practice of denying conferrals of credibility to entire populations and, as we have seen, it is sometimes backed by the authority and force of the state. Since it tends to be rooted in legal frameworks, 'fiscal impact scores', and the like, it is a form of credibility discounting that cannot easily be traced to the prejudices of individual officials - its sustaining causes are structural rather than psychological in character. So, if we accept the first tenet noted above it will be difficult to understand how epistemic redlining could qualify as an instance of epistemic injustice rather than, say, an unfortunate yet innocent error. Even if it did so qualify, it is difficult to understand how encouraging the cultivation of epistemic virtue could possibly serve as an adequate remedy for a manifestation of structural, group-based oppression. Evidently, then, epistemic redlining is not readily countenanced by existing models of epistemic injustice.

To be sure, recent years have seen growing interest in the topics of collective, institutional, and structural epistemic injustice (Anderson 2012; Fricker 2012, 2013). The few brief discussions that have emerged point to institutional culture, and to the combination of various psychological heuristics with segregation in housing, education, and the like, as additional (though still largely psychological) causes of unjust credibility discounting, alongside individual prejudice. There have also been some preliminary efforts to rough out a definition of structural epistemic injustice: Elizabeth Anderson suggests that epistemic injustice 'becomes structural when institutions are set up to exclude people without anyone having to decide to do so' $(2012,166)$. Anderson explicitly challenges the first tenet noted above, according to which credibility discounting must ultimately be traced to prejudice in order for it to be unjust. 'Why not count any mistaken credibility discounting of the speaker's testimony as a wrongful injury to the speaker as a knower?' she asks (166).

Yet Anderson's challenge raises anew the question of what it is that makes any given instance of mistaken credibility discounting unjust. Here it will not be enough to point out, as some have, that there are many factors other than prejudice that lead to bias in our credibility judgments (Faulkner 2012; Origgi 2012). Absent an argument to the effect that all instances of credibility discounting are unjust (an argument not likely to be forthcoming), it is difficult to understand how any proposed broadenings of Fricker's account might succeed (although see Maitra 2010). Moreover, Anderson's definition of structural epistemic injustice risks peremptorily excluding cases of epistemic exclusion that are structural and also the products of decisions made by one or more individuals. While it is true that institutional rules and procedures often guide our behavior in directions that run contrary to decisions we would reflectively endorse, and that resisting such rules and procedures sometimes proves costly, particularly for lone resisters, it is also the case that rules and procedures are typically the products of decisions made individually and collectively, whether through an open, democratic process or through a small group of officials opting to govern by fiat. Thus, deliberately constructed forms of structural epistemic exclusion ought to be counted as instances of epistemic injustice. 
In closing, then, I want to propose a way of circumnavigating both challenges. On the alternative account I am proposing, epistemic redlining is a structural variety of credibility discounting that ought to be understood as a form of epistemic injustice. It ought to be understood as such because Fricker's first tenet is needlessly reductionist and should not be accepted for the sake of simplicity alone. While prejudice is surely one 'ethical poison' from which epistemic injustice can be derived, it is certainly not the only or most important one. It is not even the case that all relevant poisons must be located 'in the judgement of the hearer' (and in any event, individual prejudices are dialectically related to their structural conditions, and both co-influence one another). In the case of epistemic redlining surveyed above the proximate structural causes of the blanket discrediting of populations seem to be embedded not in the judgments of individual hearers but, rather, in a series of laws adopted and enforced by the State of Michigan. In these laws, the state legislature has codified a patently false story concerning the sources of municipal fiscal distress - a story that likely originates in, and also takes advantage of, the sheer ubiquity of anti-black racism and hatred for the poor in the state and country. Through these laws, based as they are in such manifest ignorance, hundreds of thousands of Michigan residents have been unjustly excluded from testifying and being heard on matters of public policy, and from making various other epistemic contributions required for participating in the formation of the policies that most immediately shape their lives.

The structural causes of this pattern of epistemic exclusion do not lie in any single individual's judgments pertaining to the credibility of affected populations, nor are they obviously or straightforwardly the products of the judgments of any particular individual or group. Nevertheless, they have been woven into broader structural processes that continue to shape 'business as usual' in the state and that continue to result in the systematic epistemic exclusion of working-class communities of color - an outcome that is doubtless reinforced by, but does not result solely from, widespread prejudice of the sort of interest to Fricker. Given that the structural causes of such group-based exclusion would not be in place but for the epistemically dysfunctional theories of state officials and other, closely associated ideologues (views which may well be psychologically, economically, and politically functional for them and some of their supporters - see Sullivan and Tuana 2007), it stands to reason that they have not come about through mere 'innocent error'. For not only have these theories been adopted and maintained without proper regard for available evidence, but their bearers also seem to have been resisting manifest counter-evidence for years, including (but not limited to) the repeated failure of (in some cases, multiple) EFMs and EMs to 'solve' the fiscal problems of financially struggling municipalities. The theories in question are expressions of what Kristie Dotson calls 'pernicious ignorance', which is 'any reliable ignorance that, in a given context, harms another person (or set of persons)' $(2011,238)$. According to Dotson, ignorance of this sort is the root cause of epistemic violence, which includes various forms of silencing of the sort suffered in Flint and other communities facing water crises. Epistemic redlining ought to be regarded as a form of epistemic violence; and Emergency Management, an inherently violent practice.

\section{Conclusion}

The practice of Emergency Management raises anew the question of whose knowledge matters to whom and for what reasons, in light of what projects, challenges, and systemic 
imperatives. In this paper, I have argued that group-based credibility discounting remains a significant feature of ongoing projects of racialized subordination and dispossession, and that such discounting tends to have structural causes that can be difficult to identify and uproot. In officially colorblind, 'post-racial' contexts such as present-day Michigan, efforts to shore up racial hierarchies and continue extracting wealth in the midst of economic crises are increasingly employing the language of finance to justify state-level takeovers of predominantly African-American cities, and to stifle effective dissent and contestation. The language of finance plays a crucial role in the practice of epistemic redlining, which is a structural form of credibility discounting that involves denying conferrals of credibility to residents of municipalities deemed to be in a state of 'financial emergency'. Contrary to the general thrust of recent work on the topic, I have argued that epistemic redlining ought to be understood as a form of epistemic injustice in spite of the fact that it cannot be traced to prejudice and cannot be remedied through the cultivation of individual virtue.

As details of the ongoing water crises in Flint and Detroit continue to emerge, and with so much attention being devoted to identifying individual wrongdoers on whom to fix all the blame, I hope the foregoing will help to broaden conversations concerning what is to be done. Searching exclusively for a select group of blameworthy individuals is an approach very much in keeping with 'culprit-based' analyses of epistemic injustice. Yet not only do such analyses unhelpfully constrain our lines of vision, shaping which dimensions of problems are seen and understood, and which are not, they also limit our ability to address ourselves collectively to the structural aspects of the problems confronting us, which are part of fuller, more accurate pictures.

\section{Acknowledgements}

My sincerest thanks to Christine Koggel, Richard Matthews, Ami Harbin, Kathryn Norlock, and an anonymous reviewer for their invaluable feedback on earlier drafts of this paper. I would also like to thank Shea Howell, Thomas Stephens, Gloria Aneb House, Bill Wylie-Kellermann, Tawana Petty, Monica Lewis-Patrick, Debra Taylor, Marian Kramer, Maureen Taylor, Sylvia Orduño, Ann Rall, Valerie-Jean Blakely, Baxter Jones, Kim Redigan, Emily Kutil, Julia Cuneo, Kate Levy, Sarah Coffey, Fred Vitale, William Davis, and many others besides for their collective leadership and indefatigable love-waging. I am grateful to Monica Boch, Alix Davis, Jeff Davis, Áine Keefer, Joseph Longo, Kevin Mager, Trent McClain, and Mike Wolfe for responding to this work so thoughtfully and generatively. Finally, my thanks to the audiences at the Dalhousie Philosophy Colloquium Series and the 33rd International Social Philosophy Conference for engaging me in helpful discussions on these topics.

\section{Disclosure statement}

No potential conflict of interest was reported by the author.

\section{References}

Advisory Commission on Intergovernmental Relations (ACIR). 1973. City Financial Emergencies: The Intergovernmental Dimension. Washington, DC: Government Printing Office.

Anderson, M. W. 2011. "Democratic Dissolution: Radial Experimentation in State Takeovers in Local Governments." Fordham Urban Law Journal 39: 577-623.

Anderson, E. 2012. "Epistemic Justice as a Virtue of Social Institutions." Social Epistemology 26 (2): 163-173. 
Bartelt, D. W. 2010. "Redlining." In Encyclopedia of Urban Studies, edited by R. Hutchison, 643. Thousand Oaks, CA: Sage.

Berman, D. R. 1995. "Takeovers of Local Governments: An Overview and Evaluation of Sate Policies." Publius 25 (3): 55-70.

Bluestone, B., and B. Harrison. 1982. The Deindustrialization of America: Plant Closing, Community Abandonment, and the Dismantling of Basic Industry. New York: Basic Books.

Boggs, J. 1963. The American Revolution: Pages from a Negro Worker's Notebook. New York: Monthly Review Press.

Cahill, A. G., and J. A. James. 1992. "Responding to Municipal Financial Distress: An Emerging Issue for State Governments in the 1990s." Public Administration Review 52 (1): 88-94.

Cahill, A. G., J. A. James, J. E. Lavigne, and A. Stacey. 1994. "State Government Responses to Municipal Fiscal Distress: A Brave New World for State-Local Intergovernmental Relations." Public Productivity and Management Review 17: 253-264.

Cramer, J. 2015. "Race, Class, and Social Reproduction in the Urban Present: The Case of the Detroit Water and Sewage System." Viewpoint Magazine 5.

Darden, J., R. C. Hill, J. M. Thomas, and R. Thomas. 1987. Detroit: Race and Uneven Development. Philadelphia, PA: Temple University Press.

Desan, M. H., and G. Steinmetz. 2015. "The Spontaneous Sociology of Detroit's Hyper-Crisis." In Reinventing Detroit: The Politics of Possibility, edited by M. P. Smith and L. O. Kirkpatrick, 15-35. New Brunswick, NJ: Transaction.

Dimock, E. J. 1935. "Legal Problems of Financially Embarrassed Municipalities." Virginia Law Review 22 (1): 39-56.

Dimock, E. J. 1940. “Progress in Solving Municipal Insolvency Problems." Virginia Law Review 27 (2): 193-205.

Dotson, K. 2011. "Tracking Epistemic Violence, Tracking Practices of Silencing." Hypatia 26 (2): 236257.

Dotson, K. 2012. "A Cautionary Tale: On Limiting Epistemic Oppression." Frontiers 33 (1): 24-47.

Farley, R., S. Danziger, and H. Holzer. 2000. Detroit Divided. New York: Russell Sage.

Faulkner, P. 2012. "Trust and the Assessment of Credibility." Social Epistemology Review and Reply Collective 1 (8): 1-6.

Fricker, M. 2007. Epistemic Injustice. Oxford: Oxford University Press.

Fricker, M. 2010. "Replies to Alcoff, Goldberg, and Hookway on Epistemic Injustice." Episteme 7 (2): 164-178.

Fricker, M. 2012. "Silence and Institutional Prejudice." In Out from the Shadows: Analytical Feminist Contributions to Traditional Philosophy, edited by S. Crasnow and A. Superson, 287-306. Oxford: Oxford University Press.

Fricker, M. 2013. "Epistemic Justice as a Condition of Political Freedom?" Synthese 190: 1317-1332.

Glaeser, E. L. 2010. "Shrinking Detroit Back to Greatness." New York Times. Accessed July 4, 2016. http://economix.blogs.nytimes.com/2010/03/16/shrinking-detroit-back-to-greatness/.

Glaeser, E. L. 2011a. "Can Detroit Find the Road Forward?" New York Times. Accessed July 4, 2016. http://economix.blogs.nytimes.com/2011/02/22/can-detroit-find-the-road-forward/?_php= true\&_type=blogs\&_r=0.

Glaeser, E. L. 2011 b. Triumph of the City: How Our Greatest Invention Makes Us Richer, Smarter, Greener, Healthier, and Happier. New York: Penguin Press.

Glaeser, E. L. 2013. "In Detroit, Bad Policies Bear Bitter Fruit." Boston Globe. https://www.bostonglobe.com/ opinion/2013/07/23/detroit-bad-policies-bear-bitter-fruit/PHY6nyuDHfvpr3qrelPahK/story.html.

Hammer, P. J. 2016. "The Flint Water Crisis, KWA, and Strategic-Structural Racism." Written Testimony Submitted to the Michigan Civil Rights Commission Hearings on the Flint Water Crisis.

Hookway, C. 2010. "Some Varieties of Epistemic Injustice: Reflections on Fricker." Episteme 7 (2): 151163.

House Judicial Committee Democratic Staff (HJCDF). 2012. "Democracy for Sale: Subverting Voting Rights, Collective Bargaining and Accountability under Michigan's Emergency Manager Law."

Howell, S., Doan, M. D., and A. Harbin. 2016. "Detroit to Flint and Back Again: Solidarity Forever." Unpublished Manuscript. 
Hren, H., M. Morelli, and L. Briggs. 1997. "Missed Opportunity: Urban Fiscal Crises and Financial Control Boards." Harvard Law Review 110: 733-50.

Jackson, K. T. 1985. Crabgrass Frontier: The Suburbanization of the United States. New York: Oxford University Press.

Kirkpatrick, O. L., and N. Breznau. 2016. "The (Non)Politics of Emergency Political Intervention: The Racial Geography of Urban Crisis Management in Michigan." Unpublished Working Paper. Accessed July 4, 2016. http://papers.ssrn.com/sol3/papers.cfm?abstract_id=2754128.

Kwong, J. M. C. 2015. "Epistemic Injustice and Open-Mindedness." Hypatia 30 (2): 337-351.

Ladd, H. F. 1998. "Evidence on Discrimination in Mortgage Lending." The Journal of Economic Perspectives 12 (2): 41-62.

Maitra, I. 2010. "The Nature of Epistemic Injustice." Philosophical Books 51 (4): 195-211.

Malanga, S. 2009. "Feral Detroit." City Journal. Accessed July 4, 2016. http://www.city-journal.org/ $\mathrm{html} /$ feral-detroit-13242.html.

Malanga, S. 2010. "The Next Wave of Urban Reform." City Journal. Accessed July 4, 2016. http://www. city-journal.org/html/next-wave-urban-reform-13322.html.

Malanga, S. 2013. "The Real Reason the Once Great City of Detroit Came to Ruin." Wall Street Journal. Accessed July 4, 2016. http://www.wsj.com/articles/SB10001424127887324110404578625581152 645480.

Marsh, F. 2011. "Trust, Testimony, and Prejudice in the Credibility Economy." Hypatia 26 (2): 280-293.

May, S. C. 2012. "Bohman on Domination and Epistemic Injustice." Social Epistemology Review and Reply Collective 1 (8): 7-12.

Origgi, G. 2012. "Epistemic Injustice and Epistemic Trust." Social Epistemology 26 (2): 221-235.

Peck, J. 2015. "Framing Detroit." In Reinventing Detroit: The Politics of Possibility, edited by M. P. Smith and L. O. Kirkpatrick, 145-165. New Brunswick, NJ: Transaction.

Pohlhaus, G. 2012. "Relational Knowing and Epistemic Injustice: Toward a Theory of Willful Hermeneutical Ignorance." Hypatia 27 (4): 715-735.

Riggs, W. 2012. "Culpability for Epistemic Injustice: Deontic or Aretetic?" Social Epistemology 26 (2): 149-162.

Sapotichne, J., E. Rosebrook, E. Scorsone, D. Kaminski, M. Doidge, and T. Taylor. 2015. “Beyond State Takeovers: Reconsidering the Role of State Government in Local Financial Distress, with Important Lessons for Michigan and its Embattled Cities." MSU Extension White Paper.

Satter, B. 2009. Family Properties: How the Struggle Over Race and Real Estate Transformed Chicago and Urban America. New York: Picador.

Scorsone, E. A. 2014. Municipal Fiscal Emergency Laws: Background and Guide to State-Based Approaches. Working Paper 14-21. Washington, DC: Mercatus Center, George Mason University.

Scorsone, E., and N. Bateson. 2011. "Long-term Crisis and Systemic Failure: Taking the Fiscal Stress of America's Older Cities Seriously-Case Study: City of Flint." MSU Extension White Paper.

Steyn, M. 2013. "The Downfall of Detroit: It Took Only Six Decades of "Progressive" Politics to Bring a Great City to Its Knees." National Review. Accessed July 4, 2016. http://www.nationalreview.com/ article/353959/downfall-detroit-mark-steyn.

Sugrue, T. 2005. The Origins of the Urban Crisis: Race and Inequality in Postwar Detroit. Princeton, NJ: Princeton University Press.

Sullivan, S., and N. Tuana. 2007. Race and Epistemologies of Ignorance. Albany, NY: SUNY Press.

Tabb, W. K. 2015a. "If Detroit is Dead, Some Things Need to Be Said at the Funeral." Journal of Urban Affairs 37 (1): 1-12.

Tabb, W. K. 2015b. "National Urban Policy and the Fate of Detroit." In Reinventing Detroit: The Politics of Possibility, edited by M. P. Smith and L. O. Kirkpatrick, 59-74. New Brunswick, NJ: Transaction.

Turbeville, W. 2013. "The Detroit Bankruptcy." Demos. Accessed July 4, 2016. http://www.demos.org/ sites/default/files/publications/Detroit_Bankruptcy-Demos.pdf.

US Census Bureau. 2010. Summary File 1: Population and Housing Characteristics. US Census Bureau. Accessed July 4, 2016. http://factfinder.census.gov/faces/nav/jsf/pages/index.xhtml.

We The People of Detroit Community Research Collective (WTPCRC). 2016. "Mapping the Water Crisis: The Dismantling of African-American Neighborhoods in Detroit." Vol. 1. Conklin Creative. 